\title{
A History of The Librarians' Association at the University of North Carolina at Chapel Hill
}

\author{
by Brenda Ambrose-Fortune
}

7 his article examines the history of the Librarians' Association at the University of North Carolina at Chapel Hill (LAUNC-CH) from its founding in 1972 to the present. It is based on an analysis of information from archival sources of the Association at the University of North Carolina at Chapel Hill (UNC-Chapel Hill), Annual Reports of the Libraries at UNC-Chapel Hill, journal articles, and personal interviews with former officers of the Association.

\section{LAUNC-CH: A History}

Acronyms are an integral element of our language. They have become a part of our daily existence. However, their usefulness is dependent on one's knowledge of their meaning. "LAUNC-CH" (pronounced "launch") is the perfect example of an acronym that has great significance to the librarians of the University at North Carolina at Chapel Hill. LAUNC-CH is a non-profit organization comprised of current and retired professional librarians, library faculty, paraprofessional library staff, archivists, information specialists, and other persons employed in libraries at UNC-Chapel Hill. The objectives of the organization are

1. "To provide for the professional growth and development of its members;

2. To promote effective library service within the academic community;

3. To foster a spirit of cooperation among members of the library profession."

LAUNC-CH was organized under a constitution drafted on November 29, 1972, and adopted at a charter meeting on December 6, $1972 .{ }^{2}$ The Association's goal was, and is, to represent the interests of all professional librarians. Membership in the organization is divided under three categories: Member, Associate Member, and Honorary Member. The "Member" class of the Association is open to all professional librarians (i.e., anyone holding the master's degree in library and/or information science), or persons with comparable educational credentials and job classification (e.g., archivists, information specialists, etc.) at UNC-Chapel Hill. Members are eligible to vote on Association business and to serve on both the Executive Board and committees. "Associate members" are those employed in libraries at UNC-Chapel Hill not holding a professional or comparable degree, and master's and doctoral students in the School of Information and Library Science (SILS) at UNC-Chapel Hill. Associate members are ineligible to vote or serve on the Executive Board but can serve on LAUNC-CH committees. "Honorary members" are retirees of the libraries at UNC-Chapel Hill holding a professional library degree. They pay no dues; neither are they eligible to vote on Association business, serve on the Executive Board, or on committees. ${ }^{3}$ As stated in the Constitution and Bylaws of LAUNC-CH, Honorary members must annually inform the Association of their desire to continue as members.

The first officers of the UNC-CH Librarians' Association, the name used by the organization when it was founded in 1972, were Brian Nielsen, President, of the House Undergraduate Library; Rebecca Ballentine, Vice President, of the Institute of Government Library; and Elizabeth Mosby, Secretary, of R.B. House Undergraduate Library. ${ }^{4}$ The newly founded organization chose its officers and committee chairs from many libraries on campus, a fact which demonstrates the inclusiveness of the Association.

The organization was seeking an official name in the early stages of its existence. The minutes of January 10, 1973, which was the first meeting of the year, and March 26, 1973, referred to the organization as "UNC Professional Librarians' Association." In October 1973, the minutes recorded the organization's name as UNC-CH Librarians' Association. ${ }^{6}$ A brochure for 1979-1980 refers to the organization as "Association of Librarians at the University of North Carolina at Chapel Hill." This form of the name appears on the brochure for the 1980 spring conference, "Meeting the Needs of the Library's Public: Reference and Public Service in the 1980s." The conference was rescheduled for May 1980 due to inclement weather, and the new conference brochure carried that same name. The minutes of the July 19, 1979, business meeting stated that the new name was unanimously accepted. The University lawyer, Susan Ehringhaus, expressed some concern that the Association's name implied it was an official organ of the University and empowered to speak for the University. She therefore asked that the Association consider changing its name. In consultation with the University counsel, the Association chose a new name that would reflect its independent status as a group representative of all librarians on UNC-Chapel Hill campus, regardless of library affiliation. ${ }^{7}$ It was not until 1981 that the organization adopted the present name - Librarians' Association at the University of North Carolina at Chapel Hill (LAUNC-CH). 


\section{Constitution and Bylaws}

The first Constitution of the Librarians' Association at the University of North Carolina at Chapel Hill was adopted on December 6, 1972. It was amended five times. The present Constitution was adopted on January 14, 1980, and was amended eight times. The Bylaws were adopted on April 17, 1974. After being amended three times, they appeared as the Constitution and Bylaws of LAUNC-CH on July 19, 1979. They provide information on the organization's name, its objectives, membership requirements, dues, officers and their duties, guidelines on committees and their duties, the Executive Board, meetings, guidelines on amendments, and parliamentary authority. LAUNC-CH's Constitution and Bylaws must be amended any time there is a change in a committee's name, officers' duties, membership requirements, or any significant rewording of its text. The last amendment occurred in 1997. Two amendments worth explaining are the decision to create a Treasurer position, and changes in eligibility requirements.

In 1995, the organization decided that the Vice President/Treasurer/President-Elect should no longer be responsible for the duties of the Treasurer. Thus, the position of Treasurer became a separate office. The Association amended eligibility requirements for membership in 1997 to accommodate library employees with a Master's in Library Science (MLS) working in a position that does not require an MLS degree. Formerly such employees fell in the category of Associate Members. ${ }^{8}$ It is worth noting that there were but two classes of membership mentioned in the earliest written form of the Constitution - the Member and Honorary Member class.

\section{Committees}

The Association established four committees in 1972: the Committee on the Status of Librarians, the Committee on Salaries and Benefits, the Program Committee, and the Committee on Communications. ${ }^{9}$ The minutes of June 18, 1975, business meeting reported that the Committee on Communications was dissolved, while the Committee on Salaries and Benefits was merged with the Committee on the Status of Librarians. This merger produced the Committee on Professional Welfare. A new committee called the Committee on Professional Development was also introduced. ${ }^{10}$ The Professional Growth Committee, possibly the forerunner to the present Conference Committee, held a middle management workshop on May 21-22, 1976. Seventy-eight librarians from thirteen area libraries attended the workshop. Evaluation forms from the workshop indicated that participants were pleased with the result. ${ }^{11}$

A comparison of the first committees with the present ones shows the differences in their emphases then and now. When the Committee on Professional Development was established in 1975, its duties were to collect and disseminate information on continuing education opportunities, meetings, and conferences that might be of interest to Association members, and to prepare bibliographies on topics of current professional interest. ${ }^{12}$ There is no change to the committee's name as it appears in the Constitution amended in 1997. However, one always refers to the committee as the Professional Development Committee. Its duties are basically the same today. Since it no longer "prepares bibliographies on topics of current professional interest," that phrase was dropped from the committee's duties. ${ }^{13}$ The Professional Development Committee sponsors a Research Forum every year in May to which librarians from UNC-Chapel Hill and other local universities are invited to share their research with other colleagues. This is the last activity of the Association for the year.

\section{Committee on Professional Welfare}

This committee, formed as a result of a merger between the Committee on the Status of Librarians and the Committee on Salaries and Benefits, was concerned with issues relating to the clarification of the professional status and benefits of Association members. ${ }^{14}$ The primary objective of the Professional Welfare Committee, as it is referred to today, is an analysis of, and a report on, the Association of Research Libraries (ARL) Salary Survey. Members of this committee compare the salaries of librarians at UNC-Chapel Hill with those of peer institutions in the Association of Research Libraries. The committee sends a letter, generally accompanied by extensive charts, to the President of the Consolidated UNC System, the Provost, the Chancellor of UNC-Chapel Hill, the Directors of the Academic Affairs Library, the Law Library, the Health Science Library, and to local legislators of the North Carolina General Assembly. The accompanying charts illustrate UNC-Chapel Hill's ranking in comparison with peer institutions. ${ }^{15}$

\section{Committee on Programs}

At its inception, this committee planned and coordinated the monthly programs, conferences, and social activities of the Association, ${ }^{16}$ and the duties of this committee have not changed much. Though it is no longer responsible for planning the yearly conference, it sponsors monthly programs unless another committee of the Association is responsible for that month's program.

As the organization grew, more committees were added. Some are called "Standing Committees" while others are temporary — formed for a specific purpose - then dissolved. The following are the Standing Committees as they are defined in the Constitution and Bylaws of LAUNC-CH: the Committee on Professional Welfare, the Committee on Professional Development, the Program Committee, the Conference Committee, and the Publications Committee.

\section{Conference Committee}

David Taylor, chairperson of the Program Committee for 1978, recommended the formation of the Conference Committee in $1979 .{ }^{17}$ The advanced preparation required for the conference necessitated that it be managed by a different committee. The purpose of the Conference Committee is "to plan and coordinate an annual conference on a topic of general interest to the membership." 18 The Vice President/ President-Elect, in consultation with elected officers, appoints the chair and members of the Conference Committee immediately after the conclusion of the annual conference. ${ }^{19}$ This committee then serves until business relating to the next annual conference is complete.

Although the Constitution states that "the Conference Committee chair and members shall be appointed by the Vice President/PresidentElect ... immediately after the conclusion of the annual conference," the appointment rarely takes place at that time. The Conference 
Committee requires more time and devotion than any other committee. Preparations for the conference are so demanding that very few are willing to take on the task of chairing the committee. Members of the committee meet weekly throughout the planning season. They research topics suitable for the conference - topics which are of interest not only to the membership but also to prospective attendees. Members of the subcommittees within the Conference Committee make all the preparations necessary for a successful program. One or two persons who served on the last Conference Committee usually continue as members on the committee the next year. In this way the new committee will be able to begin preparation for the spring conference by drawing on experience from the past. The annual conference has always been held in March, except in 1980, when the Association rescheduled the conference due to inclement weather. ${ }^{20}$

An ad hoc committee of interested campus librarians and computer specialists planned the first conference that the Association sponsored — "Seminar on Library Automation" — held on October 6-7, 1975. Attendance was very high. There were 296 registrants; 266 library employees from North Carolina State University (NCSU), Duke University, North Carolina Central University (NCCU) and UNCChapel Hill attended. ${ }^{21}$

\section{Publications Committee}

The Publications Committee became one of the Standing Committees when the Constitution was amended in 1997. The duties of the Publications Committee are "To publish and distribute the Librarians' Association Newsletter, September through May, and to maintain the web site of the Association."22 Originally, an ad hoc Committee on Publicity distributed the Newsletter. The Newsletter was to continue on an ad hoc basis for another year with two co-editors. ${ }^{23}$ The LAUNC-CH logo, which was developed by Gregg Kemp (an artist and librarian), first appeared on the Newsletter in the March 1983 issue. ${ }^{24}$ For the first time, the editors of the Newsletter presented an annual report summarizing the highlights of the Newsletter for that year during the business meeting of June 9, 1983.

The Newsletter publishes reports of meetings, conferences, workshops, and professional activities of LAUNC-CH. It prints the names of the officers of the Association, committee chairs, and those responsible for collecting information for the Newsletter. One can access the Newsletter, information about other committees, and the Constitution of the Association from the LAUNC-CH's web site at <http://www. unc.edullib/launcchl> (viewed 7 April 2006).

\section{Social Aspects of the Association}

Each September, LAUNC-CH begins the year with a "Fall Social" organized by the Program Committee. The purpose of this gathering is to renew acquaintances, meet new colleagues, and pay one's yearly dues. The Association introduced this activity at its founding and is a traditional practice. Originally, it was labeled "The Sherry Hour." A special feature was ragtime piano music and old-time singing. On occasion there was live jazz music. This festive occasion was convened on a Friday evening in September and was also affectionately called the "Traditional Wine and Social Hour." The charge for non-members to attend was $\$ 1.00 .^{25}$ The minutes of the annual business meeting for 1975-76 tells of a Christmas party and a dinner with staff from Duke University Library in attendance. Alcoholic beverages were served during the celebration of this festive event. This practice has since been suspended because the University has prohibited the use of such beverages on campus.

\section{Dues}

Dues are collected from members to cover expenses of the Association. ${ }^{26}$ Originally, the yearly dues were $\$ 5.00$ and it remained at that price until 1996 , when it was raised to $\$ 10.00$. Members pay a reduced rate to attend the yearly spring conference as a benefit for membership in the Association. LAUNC-CH, a non-profit organization, monitors its income very carefully to maintain its tax-exempt status. By donating money to a special scholarship or sponsoring a special occasion for the members, the Association can prevent its assets from accumulating over the allowable limit.

\section{Impact of Ranking System on Librarians}

Librarians at UNC-Chapel Hill were very concerned about faculty status. They realized that they needed representation on campus. The chief architect of these plans was Brian Nielsen, a librarian then in the Circulation Department of Wilson Library on the UNC-Chapel Hill campus. He had consulted with Dr. James H. Thompson, director of the Walter Clinton Jackson Library at the University of North Carolina at Greensboro (UNC-G), and J. Isaac Copeland, director of the Southern Historical Collection at UNC-Chapel Hill. Thompson, having heard that Nielsen was involved in a study to improve the faculty status of librarians at UNC-Chapel Hill, stated in a letter to Nielsen that professional librarians at UNC-G were members of the faculty; they had full voting privileges in the Faculty Council; they served on faculty committees, both appointive and elective; but they did not have professional titles nor the provision for tenure as it was enjoyed by the teaching faculty. ${ }^{27}$ Even though librarians at UNC-G enjoyed some privileges, they desired to improve the benefits of faculty status even more. Thompson expressed to Nielsen that he wanted to know the steps that librarians at Chapel Hill would be taking to accomplish their goal, and, if they were successful in their plans, he would do the same. ${ }^{28}$ Isaac Copeland also supported Nielsen in his plans. He suggested in his letter to Nielsen that the points they should first address to the Administration were status, salaries, and benefits. He doubted whether all three would be achieved either by asking or demanding. However, he believed that "when librarians have proved themselves professionals, the doors of the academic community are open to them." 29

With support from colleagues both on and off campus, Nielsen and his newly formed organization set to work to educate its members about 
the definition, responsibilities, and benefits of faculty status. To help institute these plans, they formed two committees: the Committee on the Status of Librarians and the Committee on Salaries and Benefits. The Committee on the Status of Librarians prepared and sent out a questionnaire in rough draft on February 13, 1973, to librarians on fifteen of the sixteen University of North Carolina System institutions. The purpose of the questionnaire was to compare the faculty status of librarians on various campuses of the University System as measured against the "Standards for Faculty Status for College and University Librarians," adopted by the membership of the Association for College and Research Libraries (ACRL), Dallas, Texas, June 26, 1971..$^{30}$

Faculty status, as viewed by the Association, was a broad concept and contained such aspects as (1) Membership in Campus Governing Bodies; (2) Governance; (3) Salaries; (4) Tenure and Terms of Employment; (5) Rank; (6) Methods and Criteria for Appointments and Promotion; and (7) Access to Research Funds and Leaves. ${ }^{31}$ In the summer of 1973, the Committee on the Status of Librarians undertook a survey of all professional librarians, including faculty of the School of Library Science on the Chapel Hill campus, to assess attitudes and opinions on many of the issues relating to faculty status for librarians. The survey received a $60 \%$ response rate. Seventy-five per cent of those responses came from librarians of the Academic Affairs Library at UNC-Chapel Hill, then in the process of acquiring a new University Librarian. This new administrator, Dr. James F. Govan, wrote a letter to Brian Nielsen and expressed his need to meet with him to discuss the question of the status and tenure of librarians.

The Committee on the Status of Librarians wrote a report in which it outlined various recommendations. The report stated the need for fuller staff involvement and the implications of change in status and personnel policies for academic librarians. The Committee expected the library administrators to acknowledge the needs and recommendations expressed in the report, and to take appropriate action by changing and clarifying the policies.

The Librarians' Association fought relentlessly for its members. They held meetings with librarians from Duke University, University of Virginia, and East Carolina University to discuss resolutions for full faculty status for academic librarians on a statewide basis, and placed these resolutions before the Faculty Assembly in 1973. Also in that year, Dr. James Thompson, Director of Libraries at UNC-G, addressed members of the Association. He spoke of the differences among the System's librarians, some of whom had faculty rank and voting privileges, whereas others such as UNC-G, NCSU, and UNC-Chapel Hill, did not. Dr. Thompson wanted to present a proposal to the Board of Governors that all UNC librarians be included in the tenure and academic provisions of the Faculty Code.

Finally, in 1977, librarians at UNC-Chapel Hill were given membership in the General Faculty. A ranking system was established for librarians at that time. They did not receive faculty status, but were classed as EPA Non-Faculty. "EPA Non-Faculty employees, by North Carolina statute, are those instructional and research personnel, and senior academic and administrative officers whose salaries are fixed under the authority vested in the Board of Governors according to General Statute 116-11(5) and whose principal appointments are not faculty appointments." ${ }^{32}$ EPA Non-Faculty employees at UNC-Chapel Hill are not subject to most provisions of the State Personnel Act. All professional librarians are members of the General Faculty and have full voting rights in the Faculty Council of the University. Despite their failure to gain faculty status, UNC-Chapel Hill librarians are included on the ballots in faculty elections and participate in the faculty's self-governing body, the Faculty Council. ${ }^{33}$

\section{Significance of the Librarians' Association on Campus}

As the Association evolved, the University Library recognized it as an integral part of the library. The 1977-78 Annual Report of the University Library reported on the growth of the Association and praised its contribution to the professional development of the library staff. ${ }^{34}$

The Librarians' Association has grown considerably from a small group of librarians interested in promoting the professional growth and development of its members, providing effective library service within the academic community, and encouraging cooperation among members of the library profession into an organization whose paid membership numbers more than $100 .{ }^{35}$ The Association has advanced these goals by selecting the best speakers in their fields to deliver the keynote address for the annual conference which, each year, has attracted colleagues from the Research Triangle, other areas of North Carolina, and nearby states.

There is no doubt that the topics explored in these conferences have contributed to the success and popularity of the Association: "Library Automation" in 1975, "Collection Development" in 1977, "The New Technology" in 1982, "Reference and Public Service in the 1980s" in 1980, "Preservation in the 80s" in 1985, "Total Quality Communication" in 1993, and "Libraries in an Uncertain World" in 2002.

As the conference grew in popularity (the number of registrants increased from 78 in the Management Workshop in 1976 - the first conference with a recorded attendance count - to 225 at the conference, "Click on North Carolina: Connecting the State" in 1997), it became necessary to relocate the venue from Hanes Hall on the UNC-Chapel Hill campus to the William and Ida Friday Continuing Education Center. This new location offered better accommodation and free parking. Relocating to the Friday Center also gave the Committee more flexibility in scheduling the time the conference could be held. Of necessity, earlier conferences were scheduled during spring break, when parking became available for campus visitors. The Association publicizes the annual conference in the University Gazette, Tar Heel Libraries, College and Research Libraries News, and other state and national journals. A feature article on the 1989 conference, "The Research Library: Mission and Reality," appeared in the Chapel Hill Herald on March 14, 1989. 


\title{
Salaries
}

In the early years of its existence, the Librarians' Association was just as concerned about low salaries as it is now. There is still disparity between the salaries of librarians at UNC-Chapel Hill and those employed in comparable large research libraries. LAUNC-CH and the library administration seek diligently to improve the status of librarians at UNC-Chapel Hill, especially as it relates to salaries. As a result of continuous hard work by members of the Professional Welfare Committee, the Board of Trustees of the University unanimously approved the inclusion of EPA librarians in the distribution of salary monies generated by the tuition increase at UNC-Chapel Hill in 1999. This action may not have occurred if the Faculty Council at UNC-Chapel Hill had not passed the resolution (99-3) which called for University Administration "to work to raise librarians' salaries to a level competitive with peer institutions, and to insure that librarians participate fully in any salary increase provided to other faculty members, regardless of source of funds." 36

\section{Conclusion}

That the Librarians' Association, founded specifically for professional librarians, favors diversity in its membership is evidenced by the fact that it has amended its Constitution and Bylaws to admit paraprofessionals as members. As a demonstration of how it cares for those who are now entering the library profession, LAUNC-CH provides mentors for library science students from UNC-Chapel Hill who attend the spring conference. It sponsors monthly programs to educate the library community on various topics. These programs may be in the form of a question- and-answer session with administrators from the University or speakers' reports on conferences they attended, or bag lunch discussion on topics of interest to library staff. LAUNC-CH provides opportunities for leadership as members select new officers yearly and as the President chooses committee chairs to plan the Association's activities. It promotes professional growth by awarding scholarships to library and information science students to attend its annual conference. It provides librarians at UNC-Chapel Hill and other area universities the opportunity to share their research with others in workshops, forums or conferences. This organization has become the training ground for many who presented papers to its audiences and who now deliver papers on the state and national level. Thus, it can be said that the "local association has several distinct advantages over regional or national associations in preparing workshops or programs that will provide supplemental enrichment, especially in times of tight budgets." 37

As new leaders emerge to uphold the objectives of this organization, one envisions its continuing success. One can always find new librarians who are in search of opportunities to improve their leadership skills. By becoming involved in a local organization, new librarians may find that these small beginnings eventually can thrust them into greater responsibility in state or national organizations.

For over 30 years, many librarians have fought diligently for faculty status, better salaries and benefits, and as a result, the Librarians' Association at UNC-Chapel Hill is recognized as one of the best local associations for librarians in the Research Triangle and perhaps the state of North Carolina. The success this organization enjoys can be attributed to strong leadership, dedication, and the commitment of its members.

\section{Appendix}

\author{
Conferences Sponsored by LAUNCH-CH \\ - "Library Automation" 1975 \\ - "Library Management" 1976 \\ - "Collection Development" 1977 \\ - "Library Research" 1979 \\ - "Reference and Public Service in the 1980s" 1980 \\ - "Scholarly Publishing in the 1980s" 1981 \\ - "The New Technology" 1982 \\ - "Management of Resources: Today and Tomorrow” 1983 \\ - "Who's Afraid of Serials?" 1984 \\ - "Preservation in the 80s" 1985 \\ - "Non-Traditional Collections and Special Libraries" 1986 \\ - "Who's in Control? Managing in a Dynamic Environment" 1987 \\ - "What is a Librarian: Exploring Roles and Relationships" 1988 \\ - "The Research Library: Mission and Reality” 1989 \\ - "Information Partners for the 1990s: Libraries and Technology" 1990 \\ - "Libraries in Transition: Meeting the Needs of the Future Today" 1991 \\ - "How to Grow a Librarian: Staff Development in an Uncertain Season" 1992 \\ - “Total Quality Communication: Can We Talk?” 1993 \\ - "Do the Right Thing: Ethical Challenges in Librarianship" 1994 \\ - "The Changing Landscape of Information Services" 1995 \\ - "Library Collections in the 21st Century" 1996 \\ - "Click on North Carolina: Connecting the State" 1997 \\ - "From Virtual to Reality: A Question of Balance" 1998
}


- "Get Real: Virtual Reality and Everyday Life" 1999

- "Looking Forward, Looking Back: Content for the New Millennium" 2000

- "Digital Dilemmas: The Politics of Information in an Information Age" 2001

- "Libraries in an Uncertain World" 2002

- "New Expectations for $21^{\text {st }}$ Century Libraries" 2003

- "READ - Reading, Experiencing, Advocating, Discussing" 2004

- "Education and Practice: The Future of the Library Profession" 2005

- "Looking beyond the Five Year Plan: The Academic Library in 2005" 2006

\section{References}

${ }^{1}$ Librarians' Association at the University of North Carolina at Chapel Hill, Constitution and Bylaws, Amended 7-97. (hereafter cited as Constitution and Bylaws)

${ }^{2}$ Records of the Librarians' Association at the University of North Carolina at Chapel Hill, Manuscript Department, UNC-Chapel Hill. (hereafter cited as Records of LAUNC-CH)

${ }^{3}$ Constitution and Bylaws, Amended 7-97, p. 1.

${ }^{4}$ Minutes of UNC-CH Librarians' Association, January 10, 1973. Brian Nielsen was working at the House Undergraduate Library when he assumed the office of President of LAUNC-CH. (hereafter cited as Minutes of UNC-CH Librarians' Association)

${ }^{5}$ Ibid.

${ }^{6}$ Minutes of UNC-CH Librarians' Association, October 24, 1973.

${ }^{7}$ Minutes of UNC-CH Librarians' Association, 1974. This information was corroborated during an interview with Bernice Bergup on February 7, 1999, and another with Nancy Frazier and Celia Pratt on February 7, 2002.

${ }^{8}$ Constitution and Bylaws, Amended 7-97.

${ }^{9}$ Minutes of UNC-CH Librarians' Association, January 10, 1973.

${ }^{10}$ Business Meeting of UNC-CH Librarians' Association, June 18, 1975.

${ }^{11}$ Business Meeting of UNC-CH Librarians' Association, June 16, 1976.

${ }^{12}$ Minutes of UNC-CH Librarians' Association, October 1975.

${ }^{13}$ Constitution and Bylaws, Amended 7-97.

${ }^{14}$ Minutes of UNC-CH Librarians' Association, May 28, 1975.

${ }^{15}$ Annual Report of the Professional Welfare Committee of LAUNC-CH, June 1999.

${ }^{16}$ Constitution and Bylaws, Amended 7-97.

${ }^{17}$ David Taylor interviewed by Brenda Ambrose-Fortune, April 18, 2002.

${ }^{18}$ Constitution and Bylaws, Amended 7-97.

${ }^{19} \mathrm{Ibid}$.

${ }^{20}$ Annual Report of the Conference Committee of LAUNC-CH, 1980.

${ }^{21}$ Minutes of UNC-CH Librarians' Association, October 1975.

${ }^{22}$ Constitution and Bylaws, Amended 7-97.

${ }^{23}$ Ibid.

${ }^{24}$ Faye Phillips to Gregg Kemp, Chapel Hill, May 1982.

${ }^{25}$ Minutes of UNC-CH Librarians' Association, October 1975.

${ }^{26}$ Constitution and Bylaws, Amended 7-97.

${ }^{27}$ James H. Thompson to Brian Nielsen, Greensboro, N.C., December 29, 1972.

${ }^{28}$ Ibid.

${ }^{29}$ J. Isaac Copeland to Brian Nielsen, Chapel Hill, N.C., December 6, 1972.

${ }^{30}$ Rough Draft of questionnaire sent on February 13, 1973, to librarians of 15 of the 16 member universities of the UNC System.

${ }^{31}$ Report of the Committee on Academic Status for Librarians at UNC-Chapel Hill, December 5, 1973.

${ }^{32}$ EPA Non-Faculty Handbook, Office of Human Resources, Sect. 1, p. 9, 1992.

${ }_{33}^{3}$ Annual Report of the University Library, University of North Carolina at Chapel Hill, for the fiscal year, 1977-78, p. 11, Oct. 1978.

${ }^{34}$ Ibid. 1977-

${ }^{35}$ Records of LAUNC-CH, 1972-2000.

${ }^{36}$ Eileen McGrath, "President's Message," Librarians' Association Newsletter no. 169 (April 2000): 2.

${ }^{37}$ Janet L. Flowers, "Role of the Local Professional Association in Continuing Education," College \& Research Library News 41 (1980): 199. 